\title{
Analisis Efektifitas Metode Iqro dalam Meningkatkan Kemampuan Membaca Al- Qur'an Siswa SD
}

\author{
Subhan $^{1),}$, Firia Ningsih ${ }^{1)}$ \\ ${ }^{1)}$ STKIP Taman Siswa Bima \\ *subhantanjung@gmail.com
}

Artikel Info

Tanggal Publikasi

2020-12-15

Kata Kunci

Efektifitas Metode Iqro

Kemampuan Membaca

Al-Qur'an

\section{Abstrak}

Pembelajaran pada hakikatnya adalah interaksi antara peserta didik dengan lingkunganya sehingga terjadi perubahan perilaku kearah yang lebih baik. Dengan adanya pembelajaran tersebut banyak faktor yang mempengaruhinya, baik faktor internal yang datang dari lingkungan individu tersebut. Tujuan penelitian ini adalah untuk mengetahui efektifitas metode Iqro dalam meningkatkan kemampuan membaca Al-Qur'an siswa SD. Penelitian ini menggunakan metode penelitian kepustakaan (library research). Teknik pengumpulan data dalam artikel ini adalah dokumentasi yaitu mencari data mengenai hal-hal atau variabel yang berupa artikel/jurnal sebanyak 5 jurnal. Sedangkan teknik analisis data yang digunakan adalah analisis isi (Content Analysis). Hasil temuan penelitian ini adalah langkah-langkah pembelajaran Al-Qur'an dengan menggunakan metode Iqro yang dilaksanakan oleh para guru SD dalam mengajarkan Al-Qur'an dengan menggunakan metode Iqro sudah sangat efektif, hal ini terlihat dari kemajuan para siswanya dalam peningkatan bacaan Al-Qur'an. Kesimpulan dalam penelitian ini adalah pembelajaran Al-Qur'an dengan tercapainya target pembelajaran, dengan adanya metode Iqro rata-rata bertambahnya kualitas bacaan Al-Qur'an siswa.

\section{Pendahuluan}

Pendidikan sangatlah penting dalam kehidupan, tanpa adanya pendidikan seorang anak tidak bisa berkembang. Pendidikan adalah bagian dari upaya untuk membantu manusia memperoleh kehidupan yang bermakna hingga diperoleh suatu kebahagian hidup, baik secara individu maupun kelompok. Undang Undang No. 20 Tahun 2003 tentang Sistem Pendidikan Nasional mendefinisikan pendidikan sebagai "usaha sadar dan terencana untuk mewujudkan suasana belajar dan proses pembelajaran agar peserta didik secara aktif mengembangkan potensi dirinya untuk memiliki muatan spiritual keagamaan, pengendalian diri, kepribadian, kecerdasan, akhlak mulia, serta keterampilan yang diperlukan dirinya, masyarakat, bangsa dan negara".

Hal ini berarti bahwa pendidikan merupakan suatu proses atau upaya sadar untuk menjadikan manusia ke arah yang lebih baik. Semua tujuan pendidikan, baik pendidikan umum maupun pendidikan agama selalu mengidealkan terciptanya sikap anak didik yang dewasa, baik intelektualnya, emosionalnya, maupun spiritualnya. Menurut Muzayyin (2010:13). Pengertian pendidikan menurut ahli pendidikan di Barat antara lain: Mortimer J Adler, pendidikan adalah proses dengan dimana semua kemampuan manusia (bakat dan kemampuan yang diperoleh) yang dapat dipengaruhi oleh pembiasaan, disempurnakan dengan kebiasaankebiasaan yang baik melalui sarana yang secara artistis dibuat dan dipakai oleh siapapun. Untuk membantu orang lain atau dirinya sendiri mencapai tujuan yang ditetapkan.

Al-Abrasyi (2010: 100) memberikan pengertian bahwa pendidikan Islam adalah mempersiapkan manusia supaya hidup dengan sempurna dan bahagia, mencintai tanah air, tegap jasmaninya, sempurna budi pekertinya, teratur pikirannya, halus perasaannya, mahir dalam pekerjaannya, manis tutur katanya baik dengan lisan atau tulisan. Dari definisi tersebut Pendidikan adalah faktor yang utama dalam pembentukan pribadi manusia.

Pendidikan merupakan investasi masa depan, karena menyangkut kualitas suatu bangsa. Menyadari akan hal tersebut, pemerintah sangat serius menangani bidang pendidikan, sebab dengan sistem pendidikan yang baik 
diharapkan muncul generasi penerus bangsa yang berkualitas, yang mampu menyesuaikan diri untuk hidup bermasyarakat, berbangsa dan bernegara. Pendidikan juga berarti menyiapkan kader-kader bangsa siap pakai yang sanggup meneruskan citacita bangsa yang berdasarkan pancasila dan Undang-Undang Dasar 1945.

Pendidikan harus mampu mengarahkan kemampuan dari dalam diri manusia menjadi suatu kegiatan hidup yang berhubungan dengan tuhan (penciptanya), baik kegiatan itu bersifat pribadi maupun kegiatan bersifat sosial. Proses kependidikan itu mengandung "pengarahan" kearah tujuan tertentu. Perbuatan pendidik diarahkan pada pencapaian tujuan-tujuan tertentu, yaitu tujuan pendidikan. Tujuan-tujuan pendidikan ini bisa menyangkut kepentingan peserta didik sendiri, kepentingan masyarakat dan tuntutan lapangan pekerjaan atau ketiga-tiganya peserta didik, masyarakat dan pekerjaan sekaligus. Proses pendidikan terarah pada peningkatan penguasaan pengetahuan, kemampuan, keterampilan, pengembangan sikap dan nilai-nilai dalam rangka pembentukan dan pengembangan diri peserta didik.

Pengembangan diri ini dibutukan untuk menghadapi tugas-tugas dalam kehidupannya sebagai pribadi, sebagai siswa, karyawan, rofesional, maupun sebagai warga masyarakat. (Nana Syaodih, 2015: 4). Pembelajaran pada hakikatnya adalah interaksi antara peserta didik dengan lingkunganya sehingga terjadi perubahan perilaku kearah yang lebih baik. Dengan adanya pembelajaran tersebut banyak faktor yang mempengaruhinya, baik faktor internal yang datang dari lingkungan individu tersebut. Pembelajaran terkait dengan bagaimana membelajarkan siswa atau bagaimana membuat siswa dapat belajar dengan mudah dan dorongan oleh kemaunnya sendiri, untuk mempelajari apa yang teraktualisasikan dalam kurikulum sebagai kebutuhan peserta didik.

Oleh karena itu, pembelajaran berupaya menjabarkan nilai-nilai yang terkandung dalam kurikulum dengan menganalisis tujuan pembelajaran karakteristik isi bidang studi pendidikan agama yang terkandung dalam kurikulum. Selanjutnya dilakukan kegiatan untuk memilih, menetapkan, dan mengembangkan cara-cara metode dan strategi pembelajaran yang tepat untuk mencapai tujuan pembelajaran yang ditetapkan sesuai dengan kondisi yang ada agar kurikulum dapat diaktualisasikan dalam proses pembelajaran. (Ismail, 2018: 10). Dalam proses pembelajaran membaca, peserta didik tidak hanya harus bisa membaca tetapi harus menyukai sesuatu yang dibaca. Dengan begitu guru harus mempunyai metode pembelajaran yang khas dan metode tersebut dapat meningkatkan motivasi rasa ingin tau dan mengembangkan daya ingat.

Sasaran dan perbuatan pendidikan selalu normatif, selalu terarah kepada yang baik. Perbuatan pendidikan selalu diarahkan kepada kemaslahatan dan kesejateraan peserta didik dan masyarakat. Karena tujuannya positif, konstuktif dan normatif. Tujuan normatif tidak mungkin dapat dicapai dengan perbuatan yang tidak normatif pula. Oleh karena itu kepada guru sebagai pendidik untuk selalu berbuat, berprilaku, berpenampilan sesuai dengan norma-norma. Seorang guru memiliki peran dan tanggung jawab dalam pendidikan di sekolah. Guru adalah seorang pendidik yang profesional, karena secara implisit ia telah merelakan dirinya menerima dan memikul sebagian tanggung jawab pendidikan di pundak orang tua.

Karena sering terdengar ungkapan bahwa guru adalah orang tua disekolah. Penggunaan metode dalam pembelajaran merupakan hal yang utama dari seorang guru untuk mencapai tujuan-tujuan yang telah dirumuskan oleh sekolah. Metode merupakan salah satu bagian dari strategi kegiatan dan cara yang dalam bekerjanya sebagai alat untuk mencapai tujuan kegiatan. Suatu metode sangat penting dalam proses pembelajaran, karena metode juga menentukan berhasil atau tidaknya suatu proses kegiatan pembelajaran (Moeslichatoen, 2014: 15). Upaya strategis pembelajaran Al-Qur'an tersebut meliputi proses pemilihan pendekatan, metode, teknik pembelajaran dan prosedur pembelajaran menghasilkan hasil yang berkualitas.

Karenanya diperlukan sebuah upaya strategis untuk melaksanakan sebuah proses pendidikan agama utamanya pembelajaran Al-Qur'an, agar fungsi Alquran sebagai hudan (petunjuk) dapat berjalan sebagaimana mestinya. (Rusydan, 2012: 75) Melihat banyaknya fenomena yang terjadi yang berkaitan dengan bacaan AlQur'an. Banyak orang yang membaca Al-Qur'an tanpa memperhatikan kaidah bacaan (tajwid), sehingga dalam membacanya banyak yang salah sehingga merubah arti dari yang sebenarnya. Seperti contoh bacaan imam dalam sholat, imam dituntut untuk membaca Alquran dengan fasih menggunakan kaidah bacaan (tajwid) karena hal itu merupakan syarat untuk menjadi seorang imam. Melihat dari fenomena inilah perlu diadakan pembelajaran Al-Qur'an sejak dini.

Dalam membaca Al-Qur'an kita sebagai umat Islam dituntut untuk membaca dengan benar (fasih) sesuai dengan kaidah tajwid yang berlaku. Dari tuntutan inilah bermunculan metode-metode baca Al-Qur'an, 
diantaranya adalah Metode Klasik Alif Ba Ta, Metode Iqro, Metode Al Hira', Metode Al-Barqi, Metode Baqmi dan Metode Qiroati. Metode Alif Ba Ta adalah metode klasik yang bertahan lama. Hampir semua madrasah menerapkan metode Alif Ba Ta untuk mengajarkan Al-Qur'an. Metode ini lebih menekankan pada ejaan. Sehingga membutuhkan waktu yang lama untuk menyelesaikannya hingga mencapai Al-Qur'an. Namun beberapa kelebihan dari metode ini adalah para siswa mengenal huruf asli tanpa diberi baris. Setelah metode Alif Ba Ta hilang maka muncullah metode Iqro'. Jilid pertama dalam metode Iqro' siswa langsung mengenal huruf yang sudah diberi baris tanpa terlebih dahulu dikenalkan huruf aslinya. Sehingga siswa tidak mengenal huruf asli, namun metode ini lebih ditekankan pada baris-baris dalam bacaan. Pada metode Iqro' siswa harus menyelesaikan sampai jilid VI sehingga perlu waktu yang lama untuk menyelesaikannya.

Melihat dua metode di atas terdapat kelebihan dan kekurangan sehingga dari segi keefektifan sangat lama untuk dapat masuk kepada tahap Al-Qur'an. Untuk alasan inilah peneliti beralih kepada metode Iqro yang dipandang sebagai metode yang efektif. Pemahaman dan penguasaan Al-Qur'an bisa melalui menghafal dan tahsin Al-Qur'an. Untuk meningkatkan kemampuan bacaan Al-Qur'an siswa SD menggunakan beberapa metode dalam membantu menyelesaikan masalah yang berkaitan dengan peningkatan kemampuan bacaan. Salah satunya adalah metode Iqro. Metode Iqro dipandang sebagai metode yang efektif dalam meningkatkan kemampuan membaca Al-Qur'an siswa.

Untuk itu SD menguji metode Iqro sejauh mana metode ini lebih efektif dalam meningkatkan kemampuan membaca Al-Qur'an siswa. Secara garis besar metode Iqro adalah suatu metode membaca Al-Qur'an yang langsung memasukkan dan mempraktekkan bacaan tartil sesuai dengan kaidah ilmu tajwid. Berasal dari metode Iqro inilah kemudian banyak sekali bermunculan metode membaca Al-Qur'an seperti metode Qiroati', metode An-Nadliyah, metode Tilawaty, metode Al-Barqy dan lain sebagainya. Secara umum tujuan penelitian ini adalah untuk mengkaji efektifitas metode Iqro dalam meningkatkan kemampuan membaca Al-Qur'an.

\section{Metode}

Jenis penelitian yang digunakan adalah penelitian kepustakaan (library research). Studi kepustakaan menurut Abdi Morzaqon T. \& Budi Purwoko, (2017: 4), adalah teknik pengumpulan data dengan menelaah buku, literatur, catatan serta berbagai laporan yang berkaitan dengan masalah yang ingin dipecahkan. Lebih lanjut Zed mengemukakan bahwa dalam penelitian studi pustaka setidaknya ada empat ciri utama yang perlu diperhatikan oleh penulis, yaitu (1) Penulis atau peneliti berhadapan langsung dengan teks (nash) atau angka, bukan dengan pengetahuan langsung di lapangan. 2) Data pustaka bersifat siap pakai artinya peneliti terjun langsung kelapangan dan peneliti berhadapan langsung dengan sumber data yang ada di perpustakaan. 3) Data pustaka umumnya adalah sumber sekunder, dalam arti bahwa peneliti memperoleh bahan atau data dari tangan kedua bukan data orisinal dari data pertama di lapangan. 4) Kondisi data pustaka tidak dibatasi oleh ruang dan waktu.

Adapun Waktu dilaksanakan penelitian ini yaitu selama satu bulan. Subjek penelitian dilakukan dengan cara mengumpulkan data-data di perpustakaan dengan cara menelaah beberapa jurnal atau buku, baik yang berbentuk cetak maupun elektronik, serta sumber-sumber data dan informasi lainya yang dianggap relevan dengan penelitian atau kajian. Adapun metode atau langkah-langkah dalam penelitian ini yaitu: 1). Menidentifikasi topik penelitian, 2). Menemukan konteks dan informasi latar belakang, 3). Mencari buku, 4). Mencari artikel, 5). Mengevaluasi sumber data, 6) mengutip sumber menggunakan format atau gaya standar.

Berdasarkan langkah-langkah di atas maka tugas peneliti selanjutnya adalah menganlisis data. Data dianalisis melalui tiga tahapan, yaitu organize, synthesize, dan identify. Pertama, organize yaitu mengorganisasikan literatur-literatur yang akan digunakan. Literatur yang digunakan terlebih dahulu direviuw agar relevan atau sesuai dengan tahap permasalahan. Pada tahap ini penulis melakukan pencarian ide, tujuan, dan simpulan dari beberapa literatur dimulai dari membaca abstrak, pendahuluan, metode serta pembahasan, dan pengelompokan literature berdasarkan ketegari tertentu. Kedua, syinthesize yaitu menyusun data yang diperoleh pada tahap pertama menjadi satu ringkasan kesatuan yang padu, dengan mencari keterkaitan antar literatur. Ketiga, identify, yaitu mengidentifikasi data yang esensial dalam literatur. 


\section{Hasil dan Pembahasan}

\section{Hasil}

Pembelajaran adalah inti dari proses pendidikan secara keseluruhan dengan guru sebagai pemegang peran utama. Pembelajaran merupakan suatu proses yang mengandung serangkaian perbuatan guru dan siswa atas dasar hubungan timbal balik yang berlansung dalam situasi edukatif untuk mencapai tujuan tertentu, (Arends, 2012: 12). Lebih lanjut Arends (2012: 148) berpendapat bahwa setiap tujuan menuntut pula suatu model bimbingan untuk terciptanya situasi belajar tertentu. Pada proses belajar mengajar, tidak ada suatu model dan metode yang paling baik. Tujuan dari penelitian ini adalah untuk menganalisis keefektifan metode Iqro dalam meningkatkan kemampuan membaca A-Qur'an. Untuk mendapatkan data tersebut dilakukan kajian atau analisis dari beberapa artikel. Diantaranya adalah penelitian yang dilakukan oleh Abi Alfiah dengan judul "Efektivitas Metode Iqro' Dalam Meningkatkan kemampuan Baca Tulis Al-Qur'an Pada Siswa Kelas II di MIT Al-Mabrur Tawangsari Tahun Ajaran 2014/2015". Penelitian dilaksanakan di MIT AlMabrur Tawangsari, adapun yang menjadi sampel penelitian ini adalah siswa kelas II, dalam pelaksanaannya, penelitian ini merupakan penelitian lapangan dengan sumber data dari pimpinan MIT Al-Mabrur Tawangsari, dokumen data. Dalam pengumpulan data menggunakan metode wawancara, dokumentasi, dan observasi. Sedangkan metode analisis data adalah deskriptif kualitatif. Dari penelitian tersebut diperoleh hasil penelitian bahwa efektivitas metode Iqro yang dilaksanakan efektif, karena tercapainya indikator seperti siswa lebih aktif, penggunaan metode yang mudah dipahami, yang dilakukan guru untuk meningkatkan kemampuan siswa. Faktor pendukung dalam metode Iqro yaitu: (a) siswa yang akan mengikuti pelajaran membaca dan menulis huruf Al-Qur'an. Dengan adanya siswa dalam kegiatan belajar mengajar akan berjalan dengan baik; (b) Guru sebagai penggunaan penerapan metode agar dapat berhasil dengan baik; (c) Alokasi waktu yang digunakan dalam kegiatan ini ditentukan jadwal agar dalam penggunaan waktu yang sangat singkat ini akan terlaksana seefektif mungkin. Selain faktor pendukung, adapula faktor yang menghambat jalannya metode pembelajaran Iqro, yaitu: (a) Keadaan siswa serta latar belakang yang bermacam-macam mempengaruhi proses belajar mengajar; (b) Guru yang dituntut untuk meningkatkan kualitas kemampuannya yaitu menguasai ilmu pengetahuan, terampil dalam mengajar.

Selanjutnya penelitian yang dilakukan oleh Meda Sulistya dengan judul "Metode Iqro' Terhadap Kemampuan Membaca Huruf Hijaiyyah Anak Autis Tahun 2016". Penelitian ini dilakukan dilakukan di SLB ABC Putra Harapan Kademangan Blitar, yang menjadi sampel enelitian adalah anak autis yang memiliki hambatan membaca huruf hijaiyyah yang ditandai dengan kurang dapat menjawab pertanyaan secara lisan saat diajukan pertanyaan seputar huruf hijaiyyah oleh guru. Dalam pelaksanaannya peneliti menggunakan Metode Tes dan Metode Dokumentasi. Dari penelitian tersebut di peroleh hasil sebagai berikut: (1) sebelum dan sesudah dilakukan intervensi terhadap kemampuan membaca huruf hijaiyyah anak autis dengan menggunakan metode iqro'. Hasil pre tes anak memperoleh nilai rata-rata 51,83 dan hasil pos tes anak memperoleh nilai rata-rata 83,5. Melihat dari nilai rata-rata pre tes dan pos tes tersebut, dapat disimpulkan bahwa Metode Iqro' dapat meningkatkan kemampuan membaca huruf hijaiyyah pada anak autis di SLB ABC Putra Harapan Kademangan Blitar. (2) Dari perhitungan nilai kritis dua sisi $(1,96)$, bahwa nilai $Z$ hitung $(Z h=2,05)$ adalah lebih besar dari pada nilai kritis $5 \% \mathrm{Z}$ tabel $(\mathrm{Zt})$ dua sisi $(1,96)$ sehngga hipotesis nol (Ho) ditolak dan hipotesis kerja (Ha) diterima. Menunjukkan perubahan positif dari sebelum dan sesudah diberikan intervensi. Sehngga hasil dari penelitian ini ialah "ada pengaruh metode iqro' terhadap kemampuan membaca huruf hijaiyyah pada anak autis di SLB ABC Putra Harapan Kademangan Blitar”.

Selanjutnya penelitian yang dilakukan oleh Lina Amellia dengan judul "Efektivitas Metode Iqro Modifikasi Dengan Teknik Pembiasaan Dalam Mengingkatkan Kemampuan Mengenal Huruf Hijaiyyah Anak Usia Dini di KB Paud Melati Banda Aceh Tahun Ajaran 2017”. Penelitian ini dilakukan di KB Paud Melati Banda Acah. Sampel dalam penelitian ini adalah seluruh anak kelompok bermain PAUD Melati Banda Aceh. Dalam pelaksanaannya peneliti menggunakan instrument lembar tes, pre-test dan post-test. Dari penelitian tersebut di peroleh hasil sebagai berikut: Hasil penelitian ini menunjukkan bahwa terdapat pengaruh efektif metode Iqro modifikasi dengan teknik pembiasaan terhadap hasil belajar mengenal huruf hijaiyyah KB PAUD Melati Banda Aceh. Hal 
ini ditunjukkan dengan nilai rata-rata post test 80,625. Dapat dilihat dari hasil analisis data yaitu menggunakan uji t, serta dilakukan dengan pengujian hipotesis pada taraf signifikan $\alpha=0,05$ dan derajat kebebasan $(\mathrm{dk})=5$, di peroleh $\mathrm{t}$ hitung $=19,39$ dan $\mathrm{t}$ tabel $=1,71$, sehingga $\mathrm{t}$ hitung $>\mathrm{t}$ tabel yaitu 19,39 $>1,71$, dengan demikian HO ditolak dan H1 diterima. Hal ini menunjukkan bahwa kemampuan mengenal huruf hijaiyyah dengan metode iqro modifikasi lebih efektif di bandingkan sebelum menggunakan metode iqro modifikasi.

Selanjutnya penelitian yang dilakukan oleh Bulaeng dengan judul "Peningkatan Kemampuan Membaca AlQur'an Dengan Tartil Melalui Metode Iqra Pada Siswa Kelas V di SD Inpres Tinggimae Kecamatan Somba Opu Kabupaten Gowa Tahun 2016”. Penelitian ini dilakukan di SD Inpres Tinggimae. Sampel dalam penelitian ini adalah siswa kelas $\mathrm{V}$ sebanyak 36 siswa yang terdiri dari 20 siswa laki-laiki dan 16 siswa perempuan. Dalam pelaksanaannya peneliti menggunakan penelitian tindakan kelas (Class Action Reaserch) yang terdiri dari dua siklus dimana pada siklus I dilaksanakan sebanyak tiga kali pertemuan dan siklus II tiga kali pertemuan dengan menggunkan metode Iqra. Dari penelitian tersebut dipeoleh hasil sebagai berikut: Hasil penelitian menunjukkan dari hasil pretes atau tes pada pra tindakan memperlihatkan data antara lain skor rata-rata kelas yaitu 60,00 dengan prosentase ketuntasan dalam kelas yaitu 27,28 \%, dengan demikian masih terdapat sekitar 72,72\% siswa yang harus mendapat pengaruh yang intensif dari metode Iqro, pada siklus II skor rata-rata siswa menjadi 70,00 dengan prosentase ketuntasan dari keseluruhan menjadi 77,78 \%, atau dari jumlah 36 siswa masih ada 8 siswa yang dikategorikan belum mencapai standar kemampuan baca al-Qur'an. Berdasarkan hasil penelitian tersebut, dapat disimpulkan Kemampuan membaca Al-Qur'an dengan tartil melalui metode Iqra pada siswa kelas V di SD Inpres Tinggimae Kecamatan Somba Opu Kabupaten Gowa. Mengalami peningkatan.

Selanjutnya penelitian yang dilakukan oleh Rahmadi Ali dengan judul "Penggunaan Metode Qiroati Dalam Meningkatkan Kemampuan Membaca Al-Qur'an Siswa SDIT Bunayya Medan Tahun Ajaran 2017”. Penelitian dilakukan di SDIT Bunayya Medan. Sampel dalam penelitian ini adalah perilaku belajar siswa SDIT Bunayya Medan. Dalam pelaksanaannya peneliti menggunakan metode kualitatif yaitu suatu proses penelitian yang menghasilkan data deskriptif berupa kata-kata tertulis atau lisan dari orang-orang dan prilaku yang dapat diamati dan dilakukan pada Sekolah Dasar Islam Terpadu Bunayya Medan. Dari penelitian tersebut di peroleh hasil sebagai berikut: Memiliki pemahaman dan wawasan yang luas tentang metode-metode baca Al-Qur'an serta memiliki kemampuan dan keterampilan untuk menganalisa situasi sekarang untuk memperkirakan kejadian di masa depan sebagai input penyusunan program sekolah.

\section{Pembahasan}

Berdasarkan kajian dari beberapa artikel di atas maka dapat disajikan tabel sebagai berikut:

\begin{tabular}{|c|c|c|c|}
\hline No & Peneliti & Tahun & Hasil Penelitian \\
\hline 1 & Abi Alfiah & 2014 & $\begin{array}{l}\text { Mengungkapkan dengan menggunakan metode Iqro siswa mampu } \\
\text { meningkatkan efektifitas dan kemampuan membaca Al-Qur'an dengan baik } \\
\text { dan benar. }\end{array}$ \\
\hline 2 & $\begin{array}{l}\text { Meda } \\
\text { Sulistya }\end{array}$ & 2016 & $\begin{array}{l}\text { Menunjukkan bahwa sebelum dan sesudah dilakukan intervensi terhadap } \\
\text { kemampuan membaca huruf hijaiyyah anak autis dengan menggunakan } \\
\text { metode iqro'. Hasil pre tes anak memperoleh nilai rata-rata } 51,83 \text { dan hasil } \\
\text { pos tes anak memperoleh nilai rata-rata } 83,5 \text {. Melihat dari nilai rata-rata pre } \\
\text { tes dan pos tes tersebut, dapat disimpulkan bahwa Metode Iqro' dapat } \\
\text { meningkatkan kemampuan membaca huruf hijaiyyah pada anak autis di SLB } \\
\text { ABC Putra Harapan Kademangan Blitar. Dari perhitungan nilai kritis dua sisi } \\
\text { (1,96), bahwa nilai Z hitung (Zh=2,05) adalah lebih besar dari pada nilai kritis } \\
5 \% \mathrm{Z} \text { tabel (Zt) dua sisi }(1,96) \text { sehngga hipotesis nol (Ho) ditolak dan hipotesis } \\
\text { kerja (Ha) diterima. Menunjukkan perubahan positif dari sebelum dan } \\
\text { sesudah diberikan intervensi. }\end{array}$ \\
\hline 3 & $\begin{array}{l}\text { Lina } \\
\text { Amellia }\end{array}$ & 2017 & $\begin{array}{l}\text { Mengungkapkan bahwa terdapat pengaruh efektif metode Iqro modifikasi } \\
\text { dengan teknik pembiasaan terhadap hasil belajar mengenal huruf hijaiyyah } \\
\text { KB PAUD Melati Banda Aceh. Hal ini ditunjukkan dengan nilai rata-rata post } \\
\text { test } 80,625 \text {. Dapat dilihat dari hasil analisis data yaitu menggunakan uji t, serta } \\
\text { dilakukan dengan pengujian hipotesis pada taraf signifikan } \alpha=0,05 \text { dan } \\
\text { derajat kebebasan }(\mathrm{dk})=5 \text {, di peroleh } \mathrm{t} \text { hitung }=19,39 \text { dan } \mathrm{t} \text { tabel }=1,71 \text {, }\end{array}$ \\
\hline
\end{tabular}


sehingga $\mathrm{t}$ hitung $>\mathrm{t}$ tabel yaitu 19,39 > 1,71, dengan demikian HO ditolak dan H1 diterima.

$4 \quad$ Bulaeng 2016

$5 \quad$ Rahmadi Ali
Hasil penelitian menunjukkan dari hasil pretes atau tes pada pra tindakan memperlihatkan data antara lain skor rata-rata kelas yaitu 60,00 dengan prosentase ketuntasan dalam kelas yaitu $27,28 \%$, dengan demikian masih terdapat sekitar $72,72 \%$ siswa yang harus mendapat pengaruh yang intensif dari metode Iqro, pada siklus II skor rata-rata siswa menjadi 70,00 dengan prosentase ketuntasan dari keseluruhan menjadi $77,78 \%$, atau dari jumlah 36 siswa masih ada 8 siswa yang dikategorikan belum mencapai standar kemampuan baca al-Qur'an. Berdasarkan hasil penelitian tersebut, dapat disimpulkan Kemampuan membaca Al-Qur'an dengan tartil melalui metode Iqra pada siswa kelas V di SD Inpres Tinggimae Kecamatan Somba Opu Kabupaten Gowa. Mengalami peningkatan.

2017 Mengungkapkan bahwa dengan memiliki pemahaman dan wawasan yang luas tentang metode-metode baca Al-Qur'an serta memiliki kemampuan dan keterampilan untuk menganalisa situasi sekarang untuk memperkirakan kejadian di masa depan sebagai input penyusunan program sekolah.

Hal ini menujukan bahwa hasil penelitian ini memberikan implikasi bahwa deskripsi penelitian di atas ditemukan beberapa hal yang berhubungan dengan fokus penelitian, yaitu: Temuan pertama, Langkah-langkah pembelajaran Al-Qur'an dengan metode Iqro berlangsung secara produktif, aktif, kreatif, efektif dan menyenangkan. Sebab guru yang mengajarkan mata pelajaran Al-Qur'an di sekolah tersebut dapat mengemasnya secara menyenangkan dan tidak menjenuhkan.

Terkait dengan temuan pertama bahwa langkah-langkah atau pelaksanaan pembelajaran Al-Qur'an di SD sudah sangat efektif. Dikarenakan guru tersebut sudah bisa mengemas materi pelajaran dengan metode yang sangat menyenangkan. Namun begitu tidak boleh terlalu puas dengan hasil yang ada. Menurut hemat penulis banyak upaya-upaya yang harus dilakukan oleh guru untuk meningkatkan kualitas bacaan Alquran, yaitu: 1) Memiliki kemampuan untuk berkolaborasi dengan guru dan masyarakat di sekitar sekolah yang memiliki kemampuan bacaan Al-qur'an baik dari segi tajwid maupun tilawahnya. 2) Memiliki pemahaman dan wawasan yang luas tentang metode-metode baca Al-Qur'an. 3) Memiliki kemampuan dan keterampilan untuk menganalisa situasi sekarang untuk memperkirakan kejadian di masa depan sebagai input penyusunan program sekolah. dan 4) Memiliki kemampuan dan kemauan dalam mengidentifkasi masalah dan kebutuhan yang berkaitan dengan efektifitas pendidikan di sekolah.

Temuan kedua, hambatan yang dialami oleh para guru dalam melaksanakan metode Iqro di SD bahwa selama berjalannya proses belajar-mengajar Al-Qur'an ditemukan hambatan-hambatan yang di temukan oleh setiap kelas. Namun setelah diamati bahwa hambatan ini kebanyakan terletak pada guru, ada guru yang tidak menguasai metode Iqro, guru yang masih bertahan menggunakan metode lama, guru yang tidak bisa menguasai kelas dan sebagainya. Terkait dengan temuan kedua, bahwa jikalau hambatan tersebut terletak pada guru-guru, maka setidaknya sekolah lebih banyak membuat pelatihan-pelatihan metode Iqro. Pelatihan ini harus di jadwalkan perbulan atau persemester. Hal ini untuk membekali guru-guru yang masih kurang paham terhadap metode Iqro. Kemudian guru-guru juga harus dibekali dengan kemampuan cara mengelola kelas. Hal ini diperuntukan bagi guru yang sulit untuk menguasai kelas, apalagi karakter masing-masing siswa berbeda-beda.

Temuan ketiga, prestasi yang sudah diperoleh peserta didik SD dalam bidang bacaan Al-Qur'an. Berdasarkan pengamatan peneliti bahwa prestasi yang dihasilkan dari adanya metode Iqro rata-rata bertambahnya kualitas bacaan sehingga target pencapaian dari bacaan Al-Qur'an melewati target pembelajaran. Terkait dengan temuan ketiga ini, setidaknya prestasi tersebut tidak hanya sebatas pencapaian target pembelajaran saja, lebih dari itu prestasi harus dipupuk dan dibina ke jenjang yang lebih tinggi. Perlu juga diadakan perlombaan antar kelas yang berkaitan dengan tilawah Al-Qur'an. Agar semangat ini tidak hanya sebatas target pencapaian namun semangat berkompetisi. Kemudian ada baiknya juga siswa diikutkan perlombaan antar sekolah, agar kualitas bacaan Al-Qur'an siswa SD dapat diukur dengan sekolah lain. Hal ini untuk memacu semangat kompetisi siswa agar kualitas bacaan Al-Qur'an semakin baik. 


\section{Simpulan}

Berdasarkan hasil analisis penelitian yang telah dibahas, dapat disusun simpulan hasil penelitian adalah: Pembelajaran Al-Qur'an dengan metode Iqro yang dilaksanakan sudah sangat efektif dikarenakan guru sudah bisa mengemas materi pelajaran dengan metode yang sangat menyenangkan. Prestasi yang sudah diperoleh peserta didik SD dalam bidang bacaan Al-Qur'an. Prestasi tersebut berupa tercapainya target pembelajaran, dengan adanya metode Iqro rata-rata bertambahnya kualitas bacaan siswa. Selain itu harus memperhatikan kendala serta hambatan, hal tersebut sering terjadi pada guru, ada guru yang tidak menguasai metode Iqro, ada juga guru yang masih bertahan menggunakan metode lama, guru yang tidak bisa menguasai kelas dan sebagainya. Terkait hambatan tersebut maka setidaknya sekolah lebih banyak membuat pelatihan-pelatihan khususnya penggunaan metode Iqro, pelatihan ini harus di jadwalkan perbulan atau persemester.

\section{Daftar Pustaka}

Abdi, Mirzaqon T, \& Budi, Purwoko. (2017). Studi Kepustakaan Mengenai Landasan Teori dan Praktik Konseling Expressive Writing. Jurnal Pendidikan dan Sains. Pendidikan. Universitas Negeri Surabaya.

Abi Alfiah. 2014. "Efektivitas Metode Iqro' Dalam Meningkatkan kemampuan Baca Tulis Al-Qur'an Pada Siswa Kelas II di MIT Al-Mabrur: Tawangsari.

Al-Abrasyi, Muhammad Athiyah, al-Tarbiyah al-Islamiyah, cet.3 (Dar al-Fikr al-Arabi, tt).

Arends. R.I. (2012). Learning to Teach Ninth Edition. New Yourk: Mc Graw-Hill.

Bulaeng. "Peningkatan Kemampuan Membaca Al-Qur'an Dengan Tartil Melalui Metode Iqra Pada Siswa Kelas V di SD Inpres Tinggimae Kecamatan Somba Opu: Kabupaten Gowa.

Lina Amellia. 2017. "Efektivitas Metode Iqro Modifikasi Dengan Teknik Pembiasaan Dalam Mengingkatkan Kemampuan Mengenal Huruf Hijaiyyah Anak Usia Dini di KB Paud Melati: Banda Aceh.

Meda Sulistya. 2016. "Metode Iqro' Terhadap Kemampuan Membaca Huruf Hijaiyyah Anak Autis".

Moeslichatoen. 2014. Metode Pembelajaran di Taman Kanak-kanak. Jakarta: Rineka Cipta.

Muzayyin Arifin. 2010. Filsafat Pendidikan Islam, Cet. 5. Jakarta: PT. Bumi Aksara.

Nana Syaodih Sukmadinata. 2015. Landasan Psikologi Proses Pendidikan, Cet. 3. Bandung: Remaja Rosdakarya.

Ismail. 2018. Strategi Pembelajaran Agama Islam Berbasis PAIKEM. Semarang: Rasail Media Group.

Rahmadi Ali. 2017. "Metode Qiroati Dalam Meningkatkan Kemampuan Membaca Al-Qur'an Siswa SDIT Bunayya: Medan.

Rusydan, A. Tabrani. 2012. Pendekatan Dalam Proses Belajar Mengajar. Bandung: Remaja Rosda Karya. 